mittee, "Disturbances of Solar Origin on Communica. tions" (Naples, May 15-20) ; Structures and Materials Panel Symposium on the Material Sciences (Paris, May 15-20); Fluid Dynamics Panel (The Hague, July 17-21); Avionics Panel Technical Moeting, "Microminiaturization" (Oslo, July 24-26) ; Structures and Materials Panel Specialista' Meeting of the Material Group (Oslo, July 24-26) ; Eleventh AGARD General Assembly, "Scientific Goals of Space Exploration and Research" (Oslo, July 27-28) ; Avionics Panel Technical Meeting, "Low Noise Electronics" (Oslo, July 31-August 2).

\section{Methods of Teaching Undergraduates}

THE University Grants Committee has appointed the following committee to make a comparative study of undergraduate teaching methods and practices current in the universitios and colleges of Great Britain in the fields of arts and pure and applied science : Sir Edward Hale (chairman) ; Prof. R. G.D. Allen, professor of statistics, London School of Economics and Political Science; Dr. D. G. Christopherson, warden, Durham Colleges; Mr. J. S. Fulton, principal, University College of Sussex ; Dr. J. H. E. Griffiths, lecturer in physics, University of Oxford ; Prof. J. E. Harris, professor of zoology, University of Bristol ; Prof. A. G. Lehmann, professor of French, University of Reading ; Prof. M. McKisack, professor of history, Westfield College, University of London; Miss M. R. Price, headmistress, Milham Ford School, Oxford ; Prof. E. M. Wright, professor of mathematics, University of Aberdeen ; Mr. J. S. Morrison, lecturer in classics, University of Cambridge ; and Mr. A. Tattersall, University of Lòndon (secretary).

\section{Announcements}

Prof. W. H. MCCREA, professor of mathematics in the University of London (Royal Holloway College), has been elected president of the Royal Astronomical Society, in succession to Prof. R. O. Redman.

Lord Hurcoms, chairman of the Nature Conservancy's Committee for England and a member of its Scientific Policy and Finance Committees, has been appointed chairman of the Nature Conservancy in succession to Mr. Arthur Bryce Duncan, who is retiring from the Conservancy after a long and distinguished period of service.

Prof. A. C. Frazer, professor of melical biochemistry and pharmacology in the University of Birmingham, has been appointed a member of the Agricultural Research Council, in succession to Prof. K. Mather, who has retired.

Prof. Ritchin CaLder, professor of international relations in the University of Edinburgh, has been awarded the Kalinga Prize by Unesco for his work for the popularization of science.

Mr. R. G. Menzins, Prime Minister of Australia, is to open a new worsted processing block at the Department of Scientific and Industrial Research's Wool Industries Research Association, Torridon, Leeds, on March 22. Further information can be obtained from Norman Manners, Chief Press Officer, Charles House, 5-11 Regent Street, London, S.W.1.

Dr. Norman Dennis Newert has been awarded the Mary Clark Thompson Medal of the National Academy of Sciences, in recognition of his out- standing contributions in the field of palæontology and geology, partioularly concerning the ecology of modern and ancient calcareous reefs.

THe annual conference of the National Union of Teachers is to be held at the Dome, Brighton, during April 1-6. Further information can be obtained from Mr. F. Jarvis, National Union of Teachers, Hamilton House, Mabledon Place, London, W.C.1. The programme includes an address by $\mathrm{Mr}$. H. D. P. Lee, headmaster of Winchester College, on "Sixth Form Studies", and one by Sir Wilfrid Martineau, chairman of the Education Authorities' Panel of the Burnham Committee, on "Thoughts on Higher Education".

The Royal Photographic Society of Great Britain is organizing a three-day symposium on "Photography on Expeditions" at the Royal Geographical Society, 1 Kensington Gore, London, S.W.7, during April 11-13. Further information can be obtained from Mr. A. G. Tull, Technicolor, Ltd., Bath Road, West Drayton, Middlesex.

THE spring meeting of the British Radio Spectroscopy Group will be held at the University of St. Andrews during April 6-7. The subjects for discussion are: electron spin resonance in free radicals (April 6) and nuclear magnetic resonance, including high resolution (April 7). Further information can be obtained from D. Bijl and F. A. Rushworth, Department of Natural Philosophy, The University, St. Andrews.

THF Societz Italiana di Fisica is organizing an Enrico Fermi international school of physics at Varenna. Five courses are being held as follows : May 23-June 3, cosmic rays, solar particles and space research ; June 19-July 1, evidence for gravitational theories; July 3-15, liquid helium ; July 17August 5, semiconductors; August 7-26, nuclear physics. Further information can be obtained from Prof. G. Polvani, Società Italiana di Fisica, Via Saldini, 50-Milano.

THE Institution of Chemical Engineers is holding a one-day symposium in the Chemical Engineering Department, University of Birmingham, on April 12. Among the subjects to be considered are: "Fabrication and Properties of Some of the Newer Constructional Metals" (Dr. N. P. Inglis); "Recent Developments in Wrought Corrosion Resistant NickelBase Alloys" (E. Warde); "Plastics in Chemical Engineering and Building" (S. Slaney) ; "Glass Fibre Wound Laminates" (Dr. F. F. Jaray); "Recent High Temperature Ceramics" (Dr. A. T. Green). Further information can be obtained from T. R. Bott, Honorary Secretary, Midlands Branch, Institution of Chemical Engineers, Chemical Engineering Department, The University, Edgbaston, Birmingham 15.

THE Road Research Laboratory of the Department of Scientific and Industrial Research is holding open days on May 3-4. The work of the Materials and Construction Division and of the Tropical Section will be on show at Harmondsworth, Middlesex, while the work of the Laboratory's Traffic and Safety Division will be on show at the new Road Research Track at Crowthorne, Berkshire. The Scottish Branch of the Laboratory at Thorntonhall, near Glasgow, will be open to visitors during June 7-8. Further information can be obtained from the Press Office, Department of Scientific and Industrial Research, 5-11 Regent Street, London, S.W.1. 